\title{
Working with the World Psychiatric Association to promote dissemination of mental health research worldwide
}

\author{
Trabalhando com a Associação Mundial de Psiquiatria para \\ promover a disseminação da pesquisa em saúde mental \\ em nível mundial
}

The dissemination of research findings is important to improving mental health in all countries. ${ }^{1}$ Publishing local research information in local scientific journals can influence policy and practice at national and regional levels and encourage the expansion of cost-effective and culturally appropriate health services. International and multicultural psychiatric research is also required to understand the determinants of mental health and the options for prevention and treatment of illnesses. ${ }^{2,3}$

Where the need to improve mental health is greatest, however, the least research is available. There is a striking underrepresentation of low- and middle-income countries (LAMIC) in published psychiatric research. ${ }^{2-4}$ Barriers to the indexation of journals appear to contribute to inequitable representation of the science produced in LAMIC in the main literature databases. ${ }^{2}$

The World Psychiatric Association (WPA) decided to investigate this under-representation and considered support for improved research dissemination, building on the work from the World Health Organization $(\mathrm{WHO})^{1}$ and others. The Revista Brasileira de Psiquiatria (RBP) was one of the first LAMIC publications to be indexed in the major databases. Its achievement demonstrates the possibility for LAMIC journals to be included in the major databases as well as the peer support needed by journal editors in many countries.

The WPA's publications committee conducted a survey in the two most extensively recognised international databases of the medical and biomedical literature, Medline and ISI Web of Science (Medline/Pubmed, and the Institute for Scientific Information/ Thomson Reuters). It found 222 indexed psychiatric journals. Of these, 213 originated from high-income countries and only nine $(4.1 \%)$ were from middle-income countries: five from the European region; and four from Latin America (including RBP). None came from low-income countries and none were identified in the Asian or African regions. At the same time, the WPA zonal representatives and a project of the World Forum for Global Research and the World Bank together identified 118 LAMIC psychiatric journals not indexed in Medline or ISI. ${ }^{4}$
The committee led by CK established a directory of mental health and psychiatric journals worldwide to be linked to the WPA website. The WPA has 130 member societies in 110 countries, and with the generous help of its zonal representatives will maintain and develop the directory as a basis for advocacy and action.

A WPA publications taskforce was appointed in 2008 to promote the dissemination of research from LAMIC. The taskforce began to work together with journal editors to improve the quality of their publications and strengthen their chances of being indexed in international databases. ${ }^{5}$ Colleagues from the WPA and the Global Mental Health Movement led by JJM helped to contact editors from LAMIC in Africa, Asia, Eastern Europe, and Latin America to identify potential journals to target for indexation (Medline and ISI). The task force appraised the quality of 26 non-indexed journals whose editors were interested to participate and invited eight editors, two from each region, to attend a workshop at the World Congress of Psychiatry in 2008. The quality criteria included: affiliation to a professional mental health society; regular publication of at least 4 issues per year; comprehensive national and international editorial boards; publication of original articles, or at least abstracts, in English; some level of current indexation; evidence of a good balance between original and review articles in publications; and a friendlyaccess website. Two of the authors (JJM, former editor of RBP and CK, current associate editor) described the experience of RBP in improving the journal on each of these criteria, and the other editors described the work of their journals. Discussion established an atmosphere of peer support. Support continues with the taskforce offering continued advice through email and other forms of contact.

The taskforce aims now to offer concentrated support for those selected journals, and to assist all LAMIC mental health editors. Several journals including some whose editors have worked with the WPA project have achieved indexation in the past two years. 
The survey was repeated in 2009. Four publications were added to the databases: one from Brazil, two from South Africa, and one from Turkey. Three other journals that were indexed only in Medline two years ago are now part of the ISI database: one each from Croatia, Poland, and Turkey. Despite these inclusions, the proportion of journals from LAMIC is almost unchanged (13 of 235 [5.5\%]). ${ }^{3}$ Subsequently, the Indian Journal of Psychiatry achieved indexing in Medline.

The next step is to scale up the support for journal editors in LAMIC. The WPA taskforce provides a framework for this. The work can be monitored through the database and the network of editors. The taskforce will continue its efforts with workshops at major WPA meetings to include new editors as well as those who can describe their successful stories. It will pilot the establishment of editorial fellowships for junior editors in the office of high-quality LAMIC journals. Journals with a record in achieving high standards can join RBP, and together with funding agencies, partner with journals from LAMIC to improve their quality and strengthen their chances of being indexed.

The WPA exists to promote the advancement of psychiatry and mental health for all peoples of the world (www.wpanet.org). As part of its work plan, it continues to encourage efforts to offer support to psychiatric journals in LAMIC.

\section{Acknowledgements}

The taskforce has the following members: Helen Herrman (Chair), Jair de Jesus Mari (Co-chair), Christian Kieling, Mario Maj, Vikram Patel, Peter Tyrer, Norman Sartorius, Christopher Szabo, and Shekhar Saxena as observer. JJ Mari is a I-A level Conselho Nacional de Desenvolvimento Cientifico e Tecnológico (CNPq) Researcher.

Helen Herrman

Orygen Youth Health Research Centre, The University of Melbourne, Melbourne, Australia Secretary for Publications, World Psychiatric Association

Christian Kieling

Department of Psychiatry, Hospital de Clínicas de Porto Alegre (HCPA), Universidade Federal do Rio Grande do Sul (UFRGS), Porto Alegre (RS), Brazil

Jair de Jesus Mari

Department of Psychiatry, Universidade Federal de São Paulo (UNIFESP), São Paulo (SP), Brazil

Centre for Public Mental Health, Health Services and Population Research Department, Institute of Psychiatry, King's College, London

\section{Disclosures}

\begin{tabular}{|c|c|c|c|c|c|c|c|}
\hline $\begin{array}{l}\text { Writting group } \\
\text { member }\end{array}$ & Employment & $\begin{array}{l}\text { Research } \\
\text { grant }^{1}\end{array}$ & $\begin{array}{c}\text { Other research grant } \\
\text { or medical continuous } \\
\text { education }{ }^{2}\end{array}$ & $\begin{array}{l}\text { Speaker's } \\
\text { honoraria }\end{array}$ & $\begin{array}{l}\text { Ownership } \\
\text { interest }\end{array}$ & $\begin{array}{l}\text { Consultant/ } \\
\text { Advisory } \\
\text { board }\end{array}$ & Other $^{3}$ \\
\hline Helen Herrman & $\begin{array}{l}\text { University of } \\
\text { Malbourne }\end{array}$ & - & - & - & - & - & - \\
\hline Christian Kieling & HCPA & $\begin{array}{c}\text { CNPq } \\
\text { FIPE-HCPA }\end{array}$ & - & - & - & - & - \\
\hline $\begin{array}{l}\text { Jair de Jesus } \\
\text { Mari }\end{array}$ & UNIFESP & $\begin{array}{l}\text { FAPESP } \\
\text { CNPq } \\
\text { CAPES }\end{array}$ & - & $\begin{array}{c}\text { AstraZeneca } \\
\text { Eli Lilly } \\
\text { Janssen }\end{array}$ & - & - & - \\
\hline
\end{tabular}

* Modest

** Significant

*** Significant. Amounts given to the author's institution or to a colleague for research in which the author has participation, not directly to the author.

Note: CNPq = Conselho Nacional de Desenvolvimento Científico e Tecnológico; FIPE-HCPA = Fundo de Incentivo à Pesquisa do Hospital de Clínicas de Porto Alegre; FAPESP = Fundação de Amparo à Pesquisa do Estado de São Paulo; CAPES = Coordenação de Aperfeiçoamento de Pessoal de Nível Superior.

References

1. Saxena S, Paraje G, Sharan P, Karam G, Sadana R. The 10/90 divide in mental health research: trends over a 10 -year period. Br J Psychiatry. 2006;188:81-2.

2. Mari JJ, Patel V, Kieling C, Razzouk D, Tyrer P, Herrman H. The 5/95 gap in the indexation of psychiatric journals of low- and middle-income countries. Acta Psychiatr Scand. 2010;121(2):152-6.

3. Kieling C, Herrman H, Patel V, Tyrer P, Mari JJ. A global perspective on the dissemination of mental health research. Lancet. 2009;374(9700):1500.

4. Kieling C, Herrman H, Patel V, Mari JJ. Indexation of psychiatric journals from low and middle -income countries: a survey and case study. World Psychiatry. 2009;8(1):40-4.

5. de Jesus Mari J, Patel V, Kieling C, Anders M, Jakovljevi M, Lam LC, Lotaief F, Mendlowicz MV, Okulat G, Sathyanarayana Rao TS, Tamam L, Tyrer
P, Herrman H. The 5/95 gap in the dissemination of mental health research: the World Psychiatric Association (WPA) task force report on project with editors from low and middle income (LAMI) countries. Afr J Psychiatry (Johannesbg). 2009;12(1):33-9. 